\title{
RELATIONSHIP BETWEEN NON PERFORMING LOANS (NPL), CAPITAL ADEQUACY RATIO (CAR), LOAN TO DEPOSIT RATIO (LDR) TOWARDS RETURN ON EQUITY (ROE) AT PT. BANK CENTRAL ASIA 2014 - 2018
}

\author{
Achda Vellanita ${ }^{1}$, G Gede Arimbawa ${ }^{2}$, Elok Damayanti \\ achdavellanita@gmail.com¹, gede.arimbawa@narotama.ac.id², elok.damayanti@narotama.ac.id³ \\ Departement of Management, Faculty of Economics and Business, Narotama University \\ J1. Arief Rahman Hakim 51 Surabaya, Indonesia 60117 1,2,3
}

\begin{abstract}
This study aims to analyze the relationship of variable NPL with ROE, CAR variable with ROE, and variable LDR with ROE. This research is associative with a quantitative approach. The technique of collecting data uses the documentation and library method, which used a population of quarterly financial statements for 2014-2018 PT BCA Tbk, and it was collected 15 samples. Techniques for analyzing data using SPSS version 16. The results of this study indicate that credit risk (NPL), capital adequacy (CAR), liquidity risk (LDR) have a significant effect on financial performance (ROE). The limitations of the results of this study were only carried out at PT BCA Tbk through secondary data in the form of the 2014-2018 annual financial report. Measurement of Return On Equity (ROE) variables only through independent variables NPL, CAR, and LDR.
\end{abstract}

Keywords: NPL, CAR, LDR, ROE

\section{INTRODUCTION}

According to the Republic of Indonesia Law Number 10 of 1998 concerning banking article 1 paragraph 2 the Bank is a business entity that collects funds from the public in the form of deposits and distributes them to the public in the form of loans and / or other forms with the aim of improving people's lives. Banking operational activities are profit-oriented, the bank needs to pay attention to the aspects of profitability or the level of profit they have. Because profitability as a reference in measuring profits and profits achieved by banks is a reflection of the bank's performance in managing the funds it collects. Profitability assessment there are various indicators such as GPM, NPM, ROE and ROA used by banks.

The level of profitability is indicated by the ratio of Return on equity (ROE). Several factors can affect the level of profitability of a bank such as factors that can determine bank profitability, namely bank-specific factors, industry-specific factors, and macroeconomic factors (Arindi,2016). The level of bank profitability is shown through efforts to achieve net profit to increase company value. Various policies taken by management in an effort to increase the value of the company through increasing the prosperity of owners and shareholders reflected in the stock price. (Bringham \& Houston, 2006).

Ayu, Dewi, Sinarwati, Ari, \& Darmawan, 2014 examined the effect of Capital Adequacy Ratio (CAR), Loan To Deposit Ratio (LDR, and Comparison of Operational Costs and Operating Income (BOPO) Against Return On Assets (ROA) in Commercial Banks Listed on the Indonesia Stock Exchange In 2008-2012, the results of his research found that 1) CAR did not have a significant effect on ROA. 2) LDR does not have a significant effect on ROA. 3) BOPO has a significant effect on ROA, as well as CAR, LDR, and BOPO together have a significant effect on ROA.

While the different results shown from the results of research Hantono, 2017 on Effect Of Capital Adequacy Ratio (CAR), loan to deposit ratio (LDR) And Non Performing Loan (NPL) To Return On Assets (ROA) Listed In Banking In Indonesia Stock Exchange that : 1) Variables free of Capital Adequacy Ratio (CAR), Loan to Deposit Ratio (LDR), and Non-Performing Loans (NPL) together affect Return on Assets. 2). Partial results of the variable Capital Adequacy Ratio (CAR), Loan to Deposit Ratio (LDR), and Non Performing Loans (NPL) affect Return on Assets (ROA).

The two results of the above research show different results even though they measure the dependent variable Return on Assets (ROA) with independent variables such as: CAR, NPL and LDR. The difference in the results of this study is a reference for researchers to re-examine the role of the independent variables CAR, NPL and LDR on the Bank's financial performance, especially on Return on Equity (ROE). 
Based on the phenomenon and the results of the research above, the writer wants to re-examine the role of the NPL ratio to ROE. Besides that, the writer measures the ROE ratio by using another independent variable, Capital Adequacy Ratio (CAR) and Loan to Deposit Ratio (LDR).

\section{LITERATURE REVIEW}

\section{Noan Performing Loan (NPL)}

According to Kasmir (2010: 103), Non Performing Loans (NPL) or credit risk is the risk of possible bank losses as a result of not repaying loans given by banks to debtors. The higher the NPL ratio, the worse the quality of credit that causes the number of non-performing loans to be greater so that it can cause the possibility of a bank in the troubled condition getting bigger.

Measurement of Non-Performing Loans (NPL)

Non-performing loans are loans whose payments exceed the due date. Non-performing loans consist of bad credit, substandard loans and doubtful credit.

$$
\mathrm{NPL}=\frac{\text { Total Problem Loans }}{\text { Total Credit Given }} \times 100 \%
$$

The results of the empirical study (Kusmayadi, nd) show that the NPL has no effect and is not significant on the profitability of Return on Assets (ROA) whereas (Hantono, 2017) Non Performing Loans (NPL) has a negative effect on profitability. Both of these studies show different effects between Non Performing Loans (NPL) and Profitability (Wayan \& Capriani, 2016).

Hypothesis 1: Non Performing Loans (NPL) have a significant relationship with Return On Equity at PT Bank Central Asia Tbk

\section{Capital Adequacy Ratio (CAR)}

Capital Adequacy Ratio according to Lukman Dendawijaya (2000: 122) is a ratio that shows how far all bank assets that contain risk (credit, participation, securities, bills at other banks) are also financed from the bank's own capital funds in addition to obtaining funds from sources outside the bank, such as funds from the community, loans, etc. CAR is an indicator of a bank's ability to cover a decrease in its assets as a result of bank losses caused by risky assets.

Capital Adequacy Ratio (CAR) can be measured as follows:

$$
\mathrm{CAR}=\frac{\text { Bank Capital }}{\text { Risk Weighted Assets }(\text { ATMR })} \times 100 \%
$$

(Ayu, Dewi, Sinarwati, Ari, \& Darmawan, 2014) examined the effect of capital adequacy, and researchers found that capital adequacy had no significant and negative effect on profitability, whereas (Setiawan, 2017) said that capital adequacy had a positive and significant effect on ROA, and capital adequacy have a positive and significant effect on ROA and ROE. The results of these two research findings are different, so researchers want to re-examine the effect of capital adequacy on financial performance.

Hypothesis 2: Capital Adequacy Ratio (CAR) has a significant relationship with Return On Equity at PT Bank Central Asia Tbk

\section{Loan to Deposit Ratio (LDR)}

According to Latumaerissa, (1999: 23) LDR is a traditional measurement that shows time deposits, demand deposits, savings, etc. that are used to fulfill loan requests. This ratio is used to measure the level of liquidity. A high ratio indicates that a bank lends all its funds (loan-up) or is relatively illiquid (illiquid). On the contrary, a low ratio indicates a liquid bank with excess funding capacity that is ready to be lent.

According to (Riyadi, 2004: 146) to calculate the ratio of Loan to Deposit Ratio (LDR) there is a formula as follows:

$$
\text { LDR }=\frac{\text { Total Credit Given }}{\text { Third Party Funds }} \times 100 \%
$$

In other words, the LDR is a liquidity risk faced by banks to meet their liquidity needs to meet credit demand and all funds withdrawals by savers at once. Meanwhile BI through PBI No. 13/23 / PBI / 2011 defines liquidity risk as a risk because of the inability of banks to fulfill maturity obligations of cash flows and high quality liquid sources that can be used without disrupting activities and finances. (Ibid, Wahyudi). The problem that arises here is that the bank cannot know exactly when and how much funds will be needed or withdrawn by the debtor customer or the depositor. (Ayu et al., 2014) LDR does not have a 
significant effect on ROA. Whereas (Kusmayadi, nd) said that LDR had a positive and insignificant effect on ROA.

Hypothesis 3: Loan to Deposit Ratio (LDR) has a significant relationship with Return On Equity at PT Bank Central Asia Tbk

4. Return on Equity (ROE)

According to Kasmir (2014: 204) ROE is the ratio for measuring net income after tax with own capital. This Return on Equity ratio shows the efficiency of the use of own capital. If this ratio gets higher, the better. That means the position of the company will be stronger, and vice versa. Investors invest in companies to get returns, which consist of yields and capital gains. Where the greater the ability to make a profit, it can be ascertained the greater the expected return by investors, so that it will make the company's value better in the future.

Measurement of Return On Equity (ROE)

Return on Equity is calculated by dividing net income with shareholder equity. The way to calculate return on equity can be done using the following formula:

$$
\mathrm{ROE}=\frac{\text { Net Profit }}{\text { Equity }}
$$

\section{CONCEPTUAL FRAMEWORK}

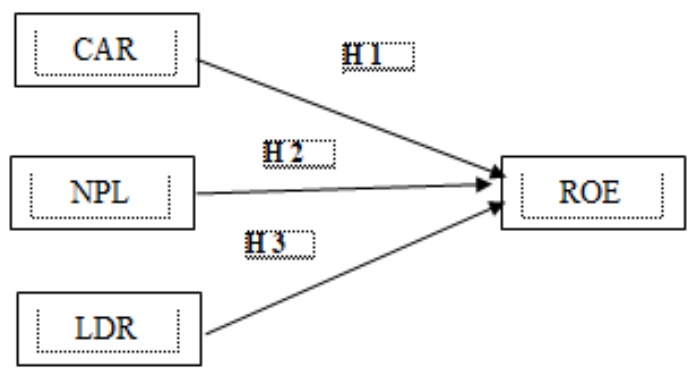

Figure 1: Research Concept Framework

\section{METHODOLOGY}

In this study the type of research used is associative research with a quantitative approach carried out at PT Bank Central Asia Tbk by using quarterly financial reports published on the official website of PT BCA Tbk, namely www.bca.co.id period 2014 - 2018. Data collection techniques using the documentation method by collecting secondary data taken from quarterly financial reports and library methods by collecting data in the form of literature on the general description of the object of research. Data analysis is done using financial ratios. Data analysis was performed by analyzing Risk profiles using NPL and LDR ratios, analyzing Capital by using CAR ratios and analyzing Earnings by using the ROE Ratio. This study uses a population of quarterly financial statements for 2014 - 2018 PT BCA Tbk, the sample collected is 15. Techniques for analyzing data using SPSS (Statistic Production Solution Service) version 16 for windows.

\section{RESULTS AND DISCUSSION}

Results of Descriptive Analysis of PT. BCA Tbk

Table 1

\begin{tabular}{|c|c|c|c|c|c|}
\hline \multicolumn{7}{|c|}{ Descriptive Statistics } \\
\hline NPL & $\mathbf{N}$ & Minimum & Maximum & Mean & Std. Deviation \\
\hline CAR & 15 & .50 & 1.50 & 1.1067 & .41656 \\
\hline LDR & 15 & 17.00 & 23.60 & 20.6467 & 2.36367 \\
\hline ROE & 15 & 74.90 & 93.80 & 85.3067 & 7.08030 \\
\hline Valid N (listwise) & 15 & 16.10 & 25.40 & 20.2200 & 2.69051 \\
\hline
\end{tabular}

Based on table 1 it can be seen that:

1. Variable is Net Performing Loan minimum(NPL) $0.50 \%$ and the value is maximum $1.50 \%$ with an average of $1.11 \%$, which means that the credit collectibility in BCA banks is in a very healthy category in 
accordance with Bank Indonesia Circular Letter Number 13/1 / PBI / 2011 criteria were very healthy with a ratio of $<2 \%$.

2. Variable Capital Adequacy Ratio (CAR), in accordance with Bank Indonesia Circular Letter Number 13/1 / PBI / 2011 criteria are very healthy with a ratio of $>15 \%$. While the condition of the capital adequacy ratio at BCA banks averaged $20.65 \%$, which means that BCA's CAR ratio is very healthy, with a minimum value of $17 \%$ and value maximum of $23.60 \%$.

3. Variable in Loan to deposit (LDR)accordance with Bank Indonesia Circular Letter Number 13/1 / PBI / 2011 is very healthy with a ratio of $70 \%$ - $<85 \%$. that the minimum value is $74.90 \%$ and the value is maximum $93.80 \%$ with an average of $85.31 \%$ which means that the liquidity risk in the BCA bank is in the healthy category.

4. Variable Return On Equity that the minimum value is $16.10 \%$ and the value is maximum $25.40 \%$ with an average of $20.22 \%$ which means that the liquidity risk in BCA banks is in a very healthy category in accordance with Bank Indonesia Circular Number 6 / 23 / DPNP / 2004 criteria are very healthy with a ratio of $>15 \%$.

\section{Data Normality Test}

In processing data in Product Moment Correlation the assumptions that must be fulfilled are normal distributed data. In this study researchers used the Kolmogorov-Smirnov Test.

Basic decision making in the Kolmogorov-Smirnov Test Normality Test.

1. If the significance value ( $\mathrm{Sig}$ ) is greater than 0.05 , the research data is normally distributed.

2. If the significance value ( $\mathrm{Sig}$ ) is less than 0.05 then the research data is not normally distributed.

Table 2

One-Sample Kolmogorov-Smirnov Test

\begin{tabular}{|c|c|c|c|c|c|}
\hline & & NPL & CAR & LDR & ROE \\
\hline \multicolumn{2}{|c|}{$\mathrm{N}$} & 15 & 15 & 15 & 15 \\
\hline Normal Parameters ${ }^{\mathrm{a}}$ & Mean & 1.1067 & 20.6467 & 85.3067 & 20.2200 \\
\hline \multirow{4}{*}{$\begin{array}{l}\text { Most Extreme } \\
\text { Differences }\end{array}$} & Std. Deviation & .41656 & 2.36367 & 7.08030 & 2.69051 \\
\hline & Absolute & .293 & .152 & .346 & .100 \\
\hline & Positive & .236 & .106 & .210 & .100 \\
\hline & Negative & -.293 & -.152 & -.346 & -.082 \\
\hline \multicolumn{2}{|c|}{ Kolmogorov-Smirnov Z } & 1.134 & .589 & 1.339 & .389 \\
\hline \multicolumn{2}{|c|}{ Asymp. Sig. (2-tailed) } & .153 & .878 & .155 & .998 \\
\hline
\end{tabular}

Source: SPSS Output Results

The results of the normality test can be seen in Table 2, it can be concluded that the magnitude of the Kolmogorov Smirnov value is 1,134 and is significant at $0.153=15.3 \%$. This means that the residual data is normally distributed because it is significant $>5 \%$ so that the regression model has met the assumption of normality.

\section{Product Moment}

Table 3

Correlations

\begin{tabular}{|c|c|c|c|c|c|}
\hline & & NPL & CAR & LDR & ROE \\
\hline \multirow[t]{5}{*}{ NPL } & Pearson Correlation & 1 & $.917^{* *}$ & $.849^{* *}$ & $-.794^{* *}$ \\
\hline & Sig. (2-tailed) & & .000 & .000 & .000 \\
\hline & $\begin{array}{c}\text { Sum of Squares and Cross- } \\
\text { products }\end{array}$ & 2.429 & 12.645 & 35.059 & -12.462 \\
\hline & Covariance & .174 & .903 & 2.504 & -.890 \\
\hline & $\mathrm{N}$ & 15 & 15 & 15 & 15 \\
\hline \multirow[t]{3}{*}{ CAR } & Pearson Correlation & $.917^{* * *}$ & 1 & $.806^{* *}$ & $-.908^{* *}$ \\
\hline & Sig. (2-tailed) & .000 & & .000 & .000 \\
\hline & $\begin{array}{c}\text { Sum of Squares and Cross- } \\
\text { products }\end{array}$ & 12.645 & 78.217 & 188.855 & -80.884 \\
\hline
\end{tabular}




\begin{tabular}{|c|c|c|c|c|c|}
\hline & $\begin{array}{c}\text { Covariance } \\
\mathrm{N}\end{array}$ & $\begin{array}{c}.903 \\
15\end{array}$ & $\begin{array}{c}5.587 \\
15\end{array}$ & $\begin{array}{c}13.490 \\
15\end{array}$ & $\begin{array}{c}-5.777 \\
15\end{array}$ \\
\hline \multirow[t]{5}{*}{ LDR } & Pearson Correlation & $.849^{* *}$ & $.806^{* *}$ & 1 & $-.704^{* *}$ \\
\hline & Sig. (2-tailed) & .000 & .000 & & .003 \\
\hline & $\begin{array}{l}\text { Sum of Squares and Cross- } \\
\text { products }\end{array}$ & 35.059 & 188.855 & 701.829 & -187.632 \\
\hline & Covariance & 2.504 & 13.490 & 50.131 & -13.402 \\
\hline & $\mathrm{N}$ & 15 & 15 & 15 & 15 \\
\hline \multirow[t]{5}{*}{ ROE } & Pearson Correlation & $-.794^{* *}$ & $-.908^{* *}$ & $-.704^{* *}$ & 1 \\
\hline & Sig. (2-tailed) & .000 & .000 & .003 & \\
\hline & $\begin{array}{l}\text { Sum of Squares and Cross- } \\
\text { products }\end{array}$ & -12.462 & -80.884 & -187.632 & 101.344 \\
\hline & Covariance & -.890 & -5.777 & -13.402 & 7.239 \\
\hline & $\mathrm{N}$ & 15 & 15 & 15 & 15 \\
\hline
\end{tabular}

Based on table 4 above can be explained as follows:

1. The relationship between Non Performing Loans (NPL) and Return on Equity (ROE) results is -0.794 with a significance level of 0.000 while $r$ table is 0.441 this means that there is a strong negative correlation, which means that any increase in the NPL ratio will reduce the ROE ratio . If the higher the NPL value, the quality of bank credit is getting worse which causes higher non-performing loans, so the company must bear losses in its operational activities and indirectly will reduce the ROE value.

2. The relationship between Capital Adequacy Ratio (CAR) and Return on Equity (ROE) results obtained at $-0,908$ with a significance level of 0,000 while $r$ table amounted to 0.441 this means there is a very strong negative correlation, which means that if capital adequacy falls then ROE also decreases . Conversely, if the CAR increases, the company's capital will also increase and the bank's income will increase.

3. The relationship between Loan to Deposit (LDR) and Return on Equity (ROE) results is -0.704 with a significance level of 0.000 while $\mathrm{r}$ table is 0.441 this means that there is a strong negative correlation, which means that any increase in the LDR ratio will increase the ROE ratio value. . The higher the credit value channeled by the bank, the higher the profit that will be obtained by the bank, because the profit is obtained from interest payments obtained from the payment of credit by the customer. The increase in profit will increase the profitability of the bank.

\section{CONCLUSION}

Based on the problems that have been formulated, the results of the analysis and testing of hypotheses that have been carried out in the previous chapter can be concluded as follows:

1. Non Performing Loans (NPL) have a strong and significant negative effect on Return On Equity (ROE). This is indicated by the regression coefficient X1 which is equal to -0.794 . The significant value of the variable Non Performing Loan (NPL)is smaller than 0.05 which is equal to 0,000 and the $r$ value of table 0.441 , so that hypothesis 1 is accepted. If a bank has a high NPL, it will increase operational costs and can disrupt the performance of the bank and can reduce the ROE value.

2. Capital Adequacy Ratio (CAR) has a very strong and significant negative effect on Return On Equity (ROE). This is indicated by the regression coefficient X2 which is equal to -0.908 . The significant value of the variable Capital Adequacy Ratio (CAR)is smaller than 0.05 which is equal to 0,000 and the $\mathrm{r}$ value of table 0.441 , so that hypothesis 2 is accepted. The higher the CAR, the higher the ROE value. This is because if a bank has a high CAR, it means that the bank has a lot of capital to carry out its operational activities and is able to bear the risk if the bank is liquidated.

3. Loan to Deposit Ratio (LDR) has a very negative and significant effect on Return On Equity (ROE). This is indicated by the X3 regression coefficient which is equal to -0.704 . Significant value of the variable Loan to Deposit Ratio (LDR) is smaller than 0.05 which is equal to 0.003 and r value of table 0.441, so hypothesis 3 is accepted. If the Loan To Deposit Ratio (LDR) increases, ROE increases, and vice versa if the Loan To Deposit Ratio (LDR) decreases, the ROE decreases. So that the higher the credit channeled by the bank, the return on Equity (ROE) of the bank will also increase

\section{LIMITATIONS}


The results of this study have limitations in exploring the independent variables that affect capital adequacy, asset quality, non-performing credit risk, liquidity and profitability and the validity of the findings of this study is not enough to describe the generalization of the impact of independent variables on the dependent variable, which does not represent the entire banking industry. Therefore, further research needs to be reexamined by independent variables other than credit risk, capital adequacy, liquidity risk that affect the company's profitability, and the involvement of the banking industry as a whole both private and government property.

\section{REFERENCES}

Aditya pratama, TE (2014). Profit Margin and Earning Per Share, 2(1).

Arindi, M. (2016). Analysis of the Effect of Credit Risk, Banking Intermediation, Liquidity Risk, and Management Efficiency on Indonesian Banking Profitability. Diponegoro Journal of Management, 5(1), $1-13$.

Ayu, K., Dewi, K., Sinarwati, NK, Ari, N., \& Darmawan, S. (2014). Effect of Capital Adequacy Ratio (CAR), Loan to Deposit Ratio (LDR), and Comparison of Operational Costs and Operating Income (BOPO) Against Return on Assets (ROA) in Commercial Banks Listed on the Indonesia Stock Exchange 20082012 e-Journal S1 Ak Universitas Pendidikan Ganesha, 2 (1).

Brigham, Eugene F and Houston. 2006. Fundamental of Financial Management: Fundamentals of Financial Management. Edition 10. Jakarta: Salemba Empat.

Dendawijaya, L. (2000). Banking management. Jakarta: Ghalia Indonesia.

Dendawijaya, L. (2005). Banking management. Jakarta: Ghalia Indonesia.

Hantono. (2017). Effect of capital adequacy ratio (car), loan to deposit ratio (ldr) and non-performing loan (NPL) to return on assets (roa) listed in banking in Indonesia stock exchange, 5(1), 69-80.

Jumono, S., Achsani, NA, Hakim, DB, \& Firdaus, M. (2014). The Impacts of ALMA Primary Variables on Profitability An Empirical Study of Indonesian Banking, 8(1), 13-32.

Kasmir. 2008. Analysis of Financial Statements. Jakarta: Rajawali Press.

Kasmir. 2010: 103. Analysis of Financial Statements. Jakarta : PT Raja Grafindo Persada

Kasmir. 2012. Analysis of Financial Statements (Fifth Print). Jakarta: PT. RajaGrafindo Persada

Kasmir. 2014. Analysis of Financial Statements. Jakarta : PT Raja Grafindo Persada

Kusmayadi, D. (n.d.). Saudi Journal of Business and Management Studies ( SJBMS ) Analysis of Effect of Capital Adequacy Ratio, Loan to Deposit Ratio, Non Performing Loan , Bopo, and Size on Return on Assets in Rural Banks at Indonesia, 6663. https://doi.org/10.21276/sjbms.2018.3.7.4

Latumaerissa, (1999: 23). Other Banks and Financial Institutions. Jakarta: Salemba Empat

Prayudi, A. (2014). Effect of Capital Adequacy Ratio (CAR), Non Performing Loans (NPL), BOPO, Return On Assets (ROA) and Net Interest Margin (NIM) on the Loan to Deposit Ratio (LDR).

Sambul, S. (2016). Stock Prices Offered on the Indonesia Stock Exchange (Case Study of 10 Banks with the Largest Assets) Influence of Financial Banking Performance To The Offered Stock Prices By Indonesia Stock Exchange (Case Study 10 Banks With The Largest Asset), 16 (2), 407-417.

Setiawan, A. (2014). Effect of Earnings Per Share (EPS), Loan To Deposit Ratio (LDR), and Operating Cash Flow on Stock Prices of Banking Sector Issuers on the Indonesia Stock Exchange, 2(2), 162-180.

Setiawan, A. (2017). Comparative Study: Determinant On Banking Profitability Between Book 4 And Book 3 Bank In, (14).

Republic of Indonesia Law. (1992). About Banking. RI Cabinet Secretariat Jakarta.

Wayan, N., \& Capriani, W. (2016). The Effect of Operational Risk Credit Risk and Liquidity Risk on the Profitability of Rural Banks in Denpasar City. E-Journal of Unud Management

www. bca.co.id 